\title{
Governing Welfare Reform Symbolically: Evidence based or iconic policy?
}

This article reports findings from an ethnographic study of welfare reform in which the discursive negotiation of policy implementation at the local level was key to understanding the phenomenon of unintended consequences. Using policy give-aways or "freebies" as a primary source of data, the article demonstrates how, despite the rhetoric of evidence based policy and practice, the meanings of policy are open to interpretation. The artifacts brand, materialize, reify, and attempt to discursively govern a range of somewhat abstract or paradoxical policy ideas in the course of implementing welfare reform. Whilst at first sight these hyper-visible manifestations of public policy may appear to be ephemeral data, on closer examination they turn out to be highly significant. They symbolize the commodification of public services, the fluid nature of policy, the uneven course of reform and the challenges of policy implementation.

Policy; branding; discourse; artifact; governance

\section{Signs of the times}

This article presents findings from an ethnographic study of policy implementation and features data in the form of artifacts. The article begins by providing brief detail on an ethnographic study that generated the data. After outlining the shifting policy context, I present five artifacts and discuss their significance. To date I have found few empirical studies using artifacts as data in policy studies; it is as though their existence has gone unnoticed. I demonstrate how what may appear at first sight to be the most ephemeral, banal data, on closer examination turned out to be highly significant. Tschirhart et al. (2005) discuss public management within a US context and they detail the complexity of solving public problems through partnerships or what they term " multi-organizational systems" (p.71) noting the 
tensions that arise when potentially competing organizations, each with their own individual brands, are expected to collaborate in the policy market place. While policy analysts with an interest in "spin", ideology or discourse usually analyze texts (Gewirtz et al. 2004), this article demonstrates the significance of signs and symbols embedded in "stuff" (Rafaeli and Pratt 2006). Without subscribing to any nihilist view that we are situated in postmodern times, I utilize selected concepts from postmodernism such as hyper-visibility (Baudrillard 1983) governmentality (Foucault 1980) and performativity (Butler 1990) to analyze the data.

In 1991 Finch suggested that "social policy as a discipline in general has paid much less attention to methodological issues than have the social science disciplines upon which it draws" (Finch 1991). Rather than assume the substance of what welfare reform or childcare policy was from an official text, I studied how policy was made sense of by those responsible for implementation. Gale's notion of temporary policy settlements (Gale 1999) informs this study. He explains the difficulty of framing a policy field:

"What the policy analyst is looking for, what is regarded as 'the policy' and/or as 'policy making', necessarily frames where and how data about policy will be found/produced." (Gale 2001, p. 383).

Policy is often paradoxical because it is designed to appeal to broad political coalitions as Stone (2002) has demonstrated and so this begs the question of how those responsible for implementing policy negotiate contradictions. Through studying implementation processes I demonstrate how policy is made and can be found through studying sense-making practices (Weick 1995).

In recent times we have seen the rise of "evidence based policy and practice" located within an instrumental, positivist paradigm (Sanderson 2003) as well as the contrasting influence on some social research of poststructuralism and postmodernism (Seidman and Wagner eds. 1992). The former can often appear to eschew values in favor of scientific objectivity. The latter may offer little of value in answer to the normative and practical question "what is to be done?" (Fraser 1981). There appears to be 
a paucity of inter-disciplinary research in which these apparently competing paradigms might be reconciled. In this case an ethnographic research design, informed by these theoretical debates, generated a data set that included a collection of found objects which became key to understanding the sense-making practices of policy implementers and the well-known phenomenon of unintended policy consequences.

\section{Iconic policy and the governance of welfare reform}

The early years childcare programme Sure Start was a "flagship" programme for New Labour, described by Tony Blair and Gordon Brown as the "jewel in the crown" of policies to tackle child poverty (Penn, 2007, p.196). Introduced in 1999, the programme fitted New Labour's modernisation discourse with its emphasis on "new ways of working". Blair claimed that no longer would policy be based on ideology but that "what matters is what works" (Newman and Clarke, 2009, p.25). Loosely informed by evidence from the US programme Head Start (Rutter 2006) the Sure Start programme comprised a set of aims and objectives related to child development, parenting and parental employment, underpinned by key performance indicators. Sure Start services were framed using a consumerist discourse of a "core offer" for parents. However, despite the apparent specificity and an investment of around $£ 3$ billion of public money, the findings of an early academic evaluation were inconclusive, with one member of the evaluation team writing: "The problem for Government is that there is no 'it' that comprises Sure Start." (Rutter 2006, p.140). Although the evaluation method entailed a longitudinal research design, the evaluation team was under pressure from politicians to report findings at an early stage and the report was released into a highly mediatized (Hajer 2009) and politicized arena. The inconclusive evidence did not lead to the abandonment of Sure Start as a failed policy. Instead, population coverage was expanded as the policy morphed into Sure Start Children's

Centres. In 2006 the brand was also applied to older people and appears in the title of a report "A Sure Start to Later Life Ending Inequalities for Older People” (Social Exclusion Unit 2006). The assumption, presumably, was that the brand was valued and so could be applied to other policy areas. 
Inevitable tensions existed from the start between the clear direction that a Government flagship programme might be expected to follow and the paradoxical aspiration to ensure the programme was also driven from the "bottom-up" (Taylor 2003) and would respond to the needs of local families. The exhortation to work in innovative ways while simultaneously following evidence based practice was also a challenge for those charged with responsibility for implementing the policy. Further ambiguities surrounded the attempts to discursively align the "protean" childcare policy (Michel and Mahon 2002, p.333) with a variety of policy initiatives ranging from the strategy to abolish child poverty, achieve social inclusion, promote welfare-to-work (by encouraging single parents in particular to place their children in formal childcare and enter the labor market) and the "tough love" Respect agenda. The incoherence of UK childcare policy is discussed by Wincott (2006) and I have previously noted the frenetic "initiativitis" that local implementers encountered (self-citation). Childcare policy became aligned with a later policy text "Every Child Matters" (DfES 2003) but welfare reform is not a straightforward, linear story of progress. With the shift from Sure Start to Sure Start Children's Centres the oxymoron of "targeted universalism" was used to defend the redistribution of resources towards families living in disadvantaged areas at the same time as extending coverage of the "core offer" to all families.

The modernization agenda imported private sector practices into public management. Neo-liberal regimes increasingly expect welfare to be delivered through non-governmental institutions such as the market and / or civil society and/or policy networks alongside public-private partnerships (Clarke et al. 2007, Newman, 2005). The dependence on the market to provide childcare for parents living in areas of disadvantage has been described as paradoxical by Pascall (2008, p.222) who frames this as "relying on the "unreliable".

At the time when I was carrying out my ethnographic study, Pricewaterhouse Coopers produced a report on the "Market for parental and family support" (PWC 2006). This analyzed "supply and demand" based on the government's own policies and concluded that, “... there are significant 
challenges associated with appropriately and adequately defining what high quality outcomes should 'look like'.” Despite this acknowledged difficulty, PWC contributed to a further HM Government publication: "Industry Techniques and Inspiration for Commissioners" (2006). This document contains advice from business gurus such as Charles Handy and presents models and "tools" such as "Business Process Reengineering, the 4 Ps Marketing Mix, and Lean Manufacturing". Case studies in the document are drawn from car manufacturing, ("We focused on our key product, Life Shine, which is a vehicle care kit comprising 24 components"), the airline industry and the construction industry ("building a gas pipeline"). This "equivalising" (Fairclough 2000, p.282) of public and private sector management techniques results in a shift away from the ideals of public service with governance predicated on principles of transparency, a commitment to a shared public interest, satisfying needs rather than wants (Fraser 1989 ) and a professional concern with meeting human needs effectively and ethically (Derhardt and Derhardt 2000); to a situation whereby "commissioners" manage the market for children's services using technocratic solutions that frame social care "outcomes" as "policy products" equivalent to any other marketised commodities (Malone 1999). The neo liberal "active investment state" (Glendinning and Kemp 2006) seeks to add value to public expenditure through attracting private sector "expertise" and/or through "empowering" active citizens to help themselves and one another through performing their civic duty in the voluntary sector, in "the community" or in what David Cameron now terms "Big Society". This concept of active welfare moves away from traditional social work with its professional-client relationships pejoratively framed as bureaucratic or "producerdriven", towards "empowering" communities, families and individuals to engage in "co-production" of welfare. In this narrative of self-reliance people are helped in order to help themselves (Miller and Stirling 2004). This has been described as a shift from government to governance (Newman 2005). However, as Newman and Clarke (2009) demonstrate, implementing welfare reform happens unevenly in contradictory and contested situations, rather than being determined via a hierarchical, controlled, linear, rational process. The artifacts that appear here symbolize what Bang has termed "culture 
governance" and but what could otherwise be termed "spin" (Gewirtz et al., 2004) or governmentality

(Rose 1989). I shall show how they are used to impose meaning through branding and reifying otherwise paradoxical policy and how an "own brand" local version of the ambiguous, oxymoronic national policy was produced.

\section{Found Objects}

In this section I outline my ethnographic research design. Rafaeli and Pratt (2006) suggest that artifacts as organizational "stuff" have been neglected in research but I did not set out to study objects when I began researching the implementation of childcare policy. I began with an interest in the topic of childcare, and an understanding derived from a review of academic literature that the relationship between childcare policy and welfare reform in general (Michel and Mahon 2002) and the role of the Sure Start programme in relation to welfare reform in particular, was contradictory and paradoxical (Wincott 2006, Stone 2002). I was interested in how those responsible for policy implementation at a local level made sense of their work and what their sense making practices (Weick 1995) entailed. The ethnographic approach allowed for an opportunistic and serendipitous approach to data collection. I accessed a Community Learning Partnership - a multi-agency partnership network situated in a disadvantaged neighborhood and created by a local authority as a delivery vehicle for implementing national UK childcare policy at a local level. This was at a time when the policy was mutating so that Sure Start local programmes became Sure Start Children's Centres, local authorities were also expected to deliver the Extended Schools initiative and these were in turn aligned (discursively at least) with the policy Every Child Matters (DfES, 2003). The partnership I studied comprised a group of teachers, youth workers, health visitors, childcare workers and voluntary and community sector representatives. The presumption in policy terms is that this form of local partnership "adds value" over and above individual agencies working in "silos" and can respond flexibly to the needs of local families. Over the course of ten months I observed a series of meetings and interviewed a sample of 55 people from statutory and voluntary agencies who all had some responsibility for Sure Start or associated public 
policies. I gathered a collection of "freebies"[1] or give-aways at meetings that were convened to promote various policy initiatives that were either closely or more loosely articulated with Sure Start. When a colleague heard of my interest in these commodities, he kindly posted me one that he had discovered. Another colleague told me how she encountered one of the artifacts that she recognized from my sample. It had turned up rhizome-like (Deleuze 1988) at an academic conference.

\section{Policy Branding}

As Rutter (2006) shows, the substance of what Sure Start is or was has proved very difficult to specify and yet the Sure Start brand was heavily stylized with branding of the local programmes centralized by the Sure Start Unit. As the programme was framed as affording discretion in implementation at local (community) level, programmes were also branded locally and local programmes adopted names such as Sure Start 4 U, or included local place names in their brand identity such as Sure Start Blurton. The tension between what DiMaggio and Powell (1983) term "isomorphic institutional" tendencies (that is, institutional standardization, with governance based on mimesis or copying) versus local autonomy is reflected in this quote from a Sure Start Programme Manager I interviewed:

"But if you go round every programme in the country we've got our midwife, our health visitor, we do our healthy eating - it's almost like walking into one of those themed bars".

Sure Start was originally intended to be rooted in the diverse experiences and needs of local communities yet the quote illustrates the limited diversification amongst Sure Start local programmes. Themed bars brand the experience of drinking. Processes of branding, standardization, predictability, calculability and control are referred to by Ritzer (2002) as "McDonaldization". Some might imagine that public services are or ought to be more than consumer commodities but similarities between consumer goods and policy products were evident in the ethnographic study. In meetings of the Community Learning Partnership, some projects such as a "sex and relationships" project were "commissioned" by selecting projects (or to use Malone's term "policy products") from a pre-prepared 
menu. At times the Community Learning Partnership acted as a purchasing organization, at other times as I will show, it produced its own tailor-made solution to policy paradoxes in the form of an innovative community circus project. Processes of branding have been analyzed by Lury (2004) to show how consumers may not be in control of their purchases as producers seek to shape their preferences using branding technologies. Lash and Urry (1994, p.3) write: "People are bombarded with signifiers and increasingly become incapable of attaching "signified" or meanings to them." The following mandatory instruction from the "branding guidelines" section from the Sure Start web-site demonstrates the attempt to control meaning and interpretation. Local implementation is apparently not intended to deviate from or challenge the values associated with the centrally driven iconic policy; all were expected to be "on message":

"The category icons have been specially drawn and should not be altered, redrawn or modified in anyway. The icons must always be reproduced from approved master artwork, available from the Sure Start Unit. Do not create your own icons. To deliver a clear and concise message the icons should be used at all times (see page 8 for further information on icon application)." http://www.Sure Start.gov.uk/resources/general/brandingguidelines [accessed 2008]. These guidelines have been updated. The branding guidelines for Sure Start Children's Centres include the following message: [accessed 24 August 2010]

The Sure Start Children's Centres brand is more than a logo; it represents a way of working, underpinned by a clear aim and a common set of principles. We expect any setting using the Sure Start Children's Centres brand to follow these principles.

As the policy shifted from the targeted nature of Sure Start towards the more universal Sure Start Children's Centres, capital funds for new buildings were substantially reduced and revenue resources were also proportionately reduced. Children's Centres are now likely to be "virtual" or "campus models" integrated with schools and existing community facilities, rather than stand alone buildings, although as long as they meet central Government criteria they may still utilise the Sure Start logos. 
Norman Glass was a senior civil servant at the Treasury and Chair of Croydon Sure Start for two years. He argues that Children's Centres are a different policy from Sure Start (Glass, 2005) but the ubiquitous brand makes it difficult to distinguish significant policy shifts. The virtual nature of the Sure Start Children's Centre programme is reflected in an exchange recorded in Parliament. The UK Government's Public Accounts Committee received a report on Sure Start Children's Centres in 2007. The record of the meeting where MPs questioned civil servants provides a fascinating insight into the complexity of accounting for public expenditure with civil servants apparently unable to provide a plausible narrative account to explain where all the money went. Some of this complexity is due to the ambiguity of the Sure Start brand and the virtual nature of Children's Centres. "Children's Centres" are and are not Sure Start. Although they use the Sure Start brand, Children's Centres are operating with proportionately significantly reduced resources. Austin Mitchell MP, a member of the Public Accounts Committee, refers to "image":

"But Sure Start told you what it was all about. Mothers can go there and learn life skills. The achievement has been wonderful — in Grimsby, it has been brilliant. But children's centres are another thing — another image ..." (House of Commons 2007, oral evidence, question 42)

Later in the Public Accounts Committee meeting, Richard Bacon MP asks a civil servant:

"Mr Bell, roughly how much of that [£20 billion] do you think has gone into Sure Start, going back to 1998?" and he replies:

David Bell: "I do not have that information to hand because the focus of the Report, and its title, is on children's centres and I have come with the data relating to the programme of children's centres." Mr Bacon : "The title of the Report is Sure Start Children's Centres."

(House of Commons 2007, oral evidence questions 84-86)

This exchange illustrates the importance of image, the iconic nature of Sure Start but also the ambiguity of the Sure Start brand. It also indicates that, despite MPs' responsibility for scrutiny, their ability to hold decision makers to account for policy decisions is not straightforward. Implementing 
"what works" is rarely a simple matter of picking an evidence based policy product off the shelf. Both image and substance appear indeterminate. We shall see the Sure Start logo appearing on an image, when I introduce the first of my artifacts in the next section.

\section{Enter the artifacts}

Here we encounter a series of seemingly unrelated commodities. What they have in common is that they have all been procured with public funds and they were gathered in the course of my research. What they variously have to say about public values is debatable. Where logos or brands could identify the local authority that generously granted me permission to carry out the ethnographic research, I have anonymized the artifacts.

\section{Sure Start Policy Artifact}

As I have been arguing, and as Rutter (2006) shows, despite rhetorical insistence that policy is evidence-based, policy can be contradictory or extremely abstract. This alien yet strangely anthropomorphic figure emanates from Sure Start. This figure measures approximately $8 \mathrm{cms}$ in length and is orange colored. Like other promotional commodities, the object performs a minimal function, in this case for time keeping.

Figure 1 Sure Start bendy figure

Its digital clock-face shows its use is time limited and historically bound. Its rubbery constitution displays a symbolic longevity designed neither for fashionable obsolescence nor organic decomposition. Promotional items are generally not designed to be valuable (except, perhaps for collectors of kitsch) but they are intended to have symbolic value as brand recognition carriers. The object doesn't hold much play value for naturally curious young children. When I received it through the post I found myself pondering on what brand loyalty it inspires and who the target audience was children or perhaps postmodern citizens in their aestheticized, hyperreal polities? Later on I wondered what it had cost and who paid. 


\section{Give respect, get respect}

Because of my assumptions that childcare policy was complex and perhaps less than coherent, I adopted a multi-sited approach to ethnography to see how various childcare discourses were being played out in different policy arenas. I collected the second of my artifacts at a Respect Agenda Health Showcase meeting held at a hotel in Central London. The UK Respect Agenda has its own brand separate from Sure Start and yet the aim of addressing "poor parenting" overlaps with the Sure Start objective of supporting disadvantaged families. Jordan and Jordan (2000) discuss the "tough love" approach to welfare reform and the discursive slippage that can occur between "support" and control. The pen is branded with the Respect logo - a near virtuous circle with arrows pointing in the same direction around the capitalized brand "respect".

Figure. 2 Respect pen

Chapter five of the UK Respect Agenda action plan begins with the gnomic statement "Everyone is part of everyone else". The Respect brand strap-line is the repetitious homily "give respect get respect". Cribb \& Owens (2010, p.1-2) discuss the function of "orchestrating labels":

What these orchestrating labels have in common is that they are benign sounding but very general and vague. They seem to point to some broad but important goods - ends which are symbolically, and in many cases literally, about inclusion. They serve as consensus and plausibility building tools in the policy tool kit; and their - very standard - ideological function is to mask value questions and disputes and to help secure assent and build coalitions. In this regard they serve a closely analogous role to that played by the even more 'value-washed' and pervasive language centered around 'effectiveness', 'efficiency' and 'evidence', that is, they play a normative role while trading on a sense of noncontentiousness."

Here the logo does not refer to the state as a potential source of "anti-social behavior" nor as a target of, 
or originator of, disrespect. Similarly to Sure Start Children's Centres, the Respect web-site had a section on "brand guidelines" that specified: "We want to ensure that everybody recognizes and values the Respect mark whenever it is used. "It continues:

"Dos and don'ts: The logo must always be produced in approved colors. (See the brand guidelines for details.) It must always be scaled proportionately. No modification can be made to the logo, as any deviation will undermine the status of the campaign."

At the meeting where I encountered these freebies, the then Minister for Public Health, Caroline Flint, appeared on the platform to display her personal commitment to tough love. In her speech she declared: “as a mum myself I sometimes have to be unpopular". She talked about working with "challenging families" and said she had to be "honest and blunt" about some families' "filthy homes". She wondered how hard it could be to "pick up a broom". This brings to mind the long running distinction noted by policy analysts between the deserving and those branded or stigmatized as the "undeserving poor" (Donzelot 1979). The Minister went on to explain how there are policy "carrots and sticks" to ensure "what is normal and acceptable". The particular initiative discussed here took the form of Family Intervention Projects intended to provide support for parents, and diversionary activities for children and young people as carrots. The sticks were the threat of eviction from social housing or the threat of children being taken into care. No need here for Rose's subtle thesis of "governance of the soul" (Rose 1989). One man sitting at my table who was working on a Family Intervention Project had brought along a photo of a client's home with what he described as "five inches of compacted dirt." This was not a formal part of the meeting. It seemed to me that he had been so shocked at finding people living in squalor that he wanted to share his experience. This voyeurism contrasts with Lister's (2002) insistence on adopting a respectful attitude towards people living in poverty. Lister notes the right of people living in poverty to participate in politics and policy making as integral to social justice. Participation was directly referred to by a showcase facilitator in the plenary session. "Although people affected by the policy were not invited here today, I think we can all agree that they have been spoken 
about very respectfully." There were no dissenting voices as people attending the meeting pocketed their freebies. My interpretation is that the absent parents had not been treated with respect but had been silenced, branded as undeserving of respect rather than included as active agents with an entitlement to a voice in policy matters.

\section{Analysing and Transforming data}

Figure 3 teddy as toy

Fig.4 teddy as policy give-away

I acquired the next freebie at an early years conference. There were the usual slide presentations from the platform followed by the opportunity to browse stalls at lunchtime. Some of these stalls sold educational toys, others presented information. The teddy's vest carries the brand of a Council's Children's Information Service which is a system designed to match up consumers and providers in the childcare market place. During the course of my research, the service was rebranded (for some reason unrelated to any evidence that I could discern) as Parent Direct. In order for me to arrive at my interpretation of this particular souvenir from my ethnographic sojourn I found it necessary to transform the artifactual data. Statisticians write about transforming data when they code and re-code their variables (deVaus 2004). In this case I removed the teddy bear's vest to transform it from a promotional item into a more commonplace but potentially more precious commodity than the freebie. This common symbol of love represents compassion, security and an "ethic of care" (Williams 2001) contrasting with the work ethic promoted by the dressed bear, by Parent Direct and by the welfare to work version of the flagship policy Sure Start. At the conference, I did not observe anyone else undressing the teddy bear or appearing to pay much attention to the freebie at all. It was dropped casually into bags along with other conference information and policy ephemera.

$\underline{\text { Needs, wants and the carnivalesque }}$ 
Amidst the proliferation of policy logos, signs and symbols, a distinction between wants and needs does persist for many public sector employees. When I talked to a secondary school head teacher he distinguished "real need" from policy advertising. He explained:

"We just haven't got the time to find the actual point of real need so you know, the mum that needs a pushchair at the bottom end of the street should be getting a push chair not a fluffy sticky bun and a tshirt that says 'Every Child Matters' she doesn't want that."

Nevertheless, the partnership that the head teacher chaired did go on to advertise itself and produced the next artifact.

Figure 5 child's paper watch

This is a child's paper watch containing the obligatory health and safety warning and a face that displays child-friendly soft juggling balls instead of numbers. I collected this freebie at a meeting of a new and emergent Community Learning Partnership network designed by a County Council as a “delivery vehicle” for implementing at a local level Sure Start Children's Centres and the later initiative Extended Schools. These partnerships were relatively ill-defined in their early days as this manager explained to me:

"Well the first task that you have is bringing people together y'know and ensuring that there's a clear message of what this is - what the core offer for extended schools is, this is what the function of a Community Learning Partnership is, this is how it can fit into the bigger picture, this is - I mean some of it has been kind of nebulous". Potter (1996) tells us: "Reifying means turning something abstract into a material thing”. It seems that the material things or artifacts attempt to reify the meaning of policy that might otherwise be regarded as ambiguous or "nebulous". The juggling metaphor frequently cropped up in Partnership meetings along with "spinning plates" as implementers described how it felt to be at the sharp end of a fast moving, "kind of nebulous" policy. It seemed they felt excited, exhilarated but also to a degree out of control as they were driven by time and money pressures with 
targets for policy implementation and a deadline for spending their allocated resources by the end of the financial year, while at the same time engaged in creating an organizational identity for the hybrid network partnership. These practical exigencies partly determined the course of policy implementation and constrained opportunities to carefully weigh evidence and consider local families' needs.

I found myself profoundly unsettled by witnessing the development of an idea for a community circus project to be performed in the round. The idea came about as a means of engaging local children and their families in a fun activity that could also achieve educational and "social inclusion" goals. What I have termed the "elastic-policy-project" (Carter 2009) enabled a range of diverse partners which included people from a further education college, a voluntary run out of school club, a housing regeneration agency, a youth worker and so on to assemble (Newman and Clarke 2009) mutual objectives and simultaneously articulate their own policy agendas and to translate these into a uniquely local project that manifested as an unintended outcome of centrally determined policy. The creative circus idea seemed a long way from a discourse of managerialist evidence based policy with its insistence on delivering efficient, strategic outcomes. Critical analysts will recognize that bread and circuses was a well-known diversionary tactic used by the Romans to entertain the masses. Boje draws on Bakhtin and others noting that "Contemporary carnival is a polyphonic (many voiced) expression by those without power, sometimes sanctioned by those in power as a way to blow off steam" (Boje 2001, p. 438). And yet here the promotion of the spectacular opened up the possibility of members of the local community performing a positive public image rather than being subject to the policy gaze, specified as an object of policy as a "disadvantaged community" or a "deprived neighborhood". Public funds were turned, not into individualized policy “outcomes" directly related to childcare or family support but into a different kind of creative performance management in a radically indeterminate community space and time. There was no "proscenium arch", no clearly delineated detached observer perspective through which I might access the meaning of this very particular and yet quite abstract circus, scheduled to take place at some unspecified time in the near future but already producing 
juggling effects in the present.

\section{Highlighting own-brand local policy translation}

Figure 6 highlighter pen

I was presented with this artifact at a meeting of the Community Learning Partnership. Partnership is a highly normative term and partnership working is usually expected to happen by consensus. As Newman and Clarke express it "The language of egalitarian cooperation that saturates partnership is almost as 'warm' as the idea of community." ( Newman and Clarke, 2009, p.60). Despite this consensual appearance and the "feel-good factor" of the exciting circus project, some teachers who were present at one meeting of the partnership that I attended raised a challenge by querying the validity of the highlighter pens. They questioned which members of the partnership had authorized expenditure for the freebie and challenged whether, in relation to what local families needed, they represented value for money. The juggling balls had become the Partnership's own brand logo but the expenditure of public money on the brand carrier, the highlighter was contested. These teachers insisted that their own institutions (schools) were held to account and governed by a formalized set of rules and procedures and queried whether the Partnership's decisions were made transparently. This challenge was not upheld. They were given the explanation by a Sure Start manager that the Community Learning Partnership was expected to work in innovative ways; the network needed to quickly establish its organizational identity to move from a "nebulous" state towards a credible organization which could promote its identity with a recognizable brand. The partnership also faced an imperative of spending its allocated resources by the end of financial year. Purchasing the highlighter pens avoided the dreaded "underspend" which could have risked the perception that the partnership was an unreformed, old fashioned, sclerotic organization, incapable of working in new ways and successfully "delivering" 
policy. Teachers were discursively enrolled into the partnership by the Sure Start manager through framing the circus project not as a childcare project, nor as tough love or a welfare to work initiative but as an opportunity to offer local families a chance to celebrate their collective local community identity and perform in public. This in turn was re-framed and translated by a manager in the partnership, drawing not on evidence of local need but on the discourse from yet another policy text, the Roberts Review of creativity and culture (Roberts 2006) translating the "interpretative repertoire" (Potter 1996) of the Partnership to include the objective of educational attainment. In this lexicon, the circus became an out of school enrichment activity, discursively aligned not with contentious welfare reform but with schools' teaching and learning "core business". The highlighter has similarities with a “boundary object" (Star and Griesemer, 1989). These authors explain:

"In conducting collective work, people coming together from different social worlds frequently have the experience of addressing an object that has a different meaning for each of them. Each social world has partial jurisdiction over the resources represented by that object, and mismatches caused by the overlap become problems for negotiation."

The circus project enabled the partners as people from different worlds to negotiate policy implementation and the object's equilateral triangular shape symbolizes the attempts to stabilize the organizational boundaries of the hybrid Community Learning Partnership as it metamorphosed ideas about public value, community co-optation / empowerment and entrepreneurial culture governance into a fetish artifact. The tension between meeting top-down implementation timetables with targets for expenditure and working creatively at the local level was resolved by envisioning a plan for a circus project to take place at some unspecified date in the next financial year but spending ahead from the current budget on the circus related give-aways. The implementation practices of discursive negotiation, creating the uniquely local project, branding and expedient decision making all contrast with the notion of value-free, carefully weighed and adjudicated evidence that might inform policy and practice. 


\section{Iconoclasm}

Despite practices of governmentality that attempt to brand, commodify and materialize policy, the meaning of childcare policy remains protean (Michel and Mahon 2002), shifting its shape according to policy initiativitis and according to the interpretive processes of implementation. Although the Sure Start brand may be recognizable, the content of the programme is amoeba-like, partially dependent upon central Government specification of the Children's Centres and Extended Schools core offer but shifting its polysemic shape according to the ideas and decisions that produce the particular local policy palimpsest (self-citation). Sure Start was re-branded as Sure Start Children's Centres but it is not clear whether these are distinct policies, more of the same with added branding or whether they represent a substantially reduced commitment to tackle child poverty or a further shift towards neo-liberal welfare reform. What is clear that Children's Centres are more likely to be 'virtual' manifestations of childcare policy comprising a set of branded commissioned services, rather than clearly identifiable, physical stand alone Centres.

The ways in which policy implementers made sense of vague or contradictory policy included attempts at reification through symbolizing meaning in give-ways or freebies. The highlighter pen, like the House of Commons reported exchange, symbolizes not governmental transparency but the opacity of decision making. I am not prepared to be completely seduced by the objects in my data set. For me they do not represent objects of desire. The ethnographic data reveals the give-away that is the connection between the economic and the symbolic (Jessop and Oosterlynck. 2008, Willis 2000); between public money and decisions taken in private, between ideas of duty, service and the public good and market place, promotional, branded culture. These commodities are surely intended to function as "mere symbols" (Rafaeli and Pratt 2006) as carriers for brand recognition. This form of data is hypervisible in policy implementation arenas - freely available and yet grossly understudied. Promotional items, "give-aways" or "freebies" are not intended to be useful or particularly meaningful. There is no return for give-aways - no refunds are permitted. The artifacts market policy and equate policy administration 
and public governance with business-like practices and principles. In so doing they risk giving away the idea of public value as separate from the market. The commodities symbolize for me the risk of squandering hard won citizenship rights to hold policy makers (whether politicians or public servants) to account and they brand citizens as symbolic consumers or even (like the non-participants absent from the Respect Agenda Health Showcase meeting) as voiceless quasi-objects of the virtual community-society-market-place. The fetishization of market values (lean manufacturing, business process re-engineering, etc) that equates public with private management authorizes those who produce and market the logos and icons to persuade us that policy is in our best interests, misrepresenting the sovereign people whose individual, joint and several interests ought to be formed in a dialectical ongoing societal and political relationship. Mitchell, writing about the rebranding of the UK anti social behavior orders (Mitchell 2011) noted that

“... in general, we should avoid changing the names of aspects of the state or government because politicians' tendency will always be to make the new names more emotive, more like adverts. And the government has nothing to sell us that we don't already own."

For me the fact of the artifacts' public money provenance - their very specific relationship to the public domain (which ought to be beyond price yet is not currently free nor equal) means that, although they might be worthless to some, they could be priceless for critical researchers seeking points of intervention in a culture of consumption and a political economy of signs. Unless we are prepared to become iconoclasts, prepared to disrupt and dis-respect the policy brands and logos we risk being consumed by publicity. The legacy of a public sphere with a universal system of welfare from cradle to grave may have existed only in the imagination but its visionary symbolism is seriously undermined by a public sphere where everything is up for commodification and sale. The life course of the policies symbolized in the artifacts in my data set show that one policy has apparently deceased (the now defunct Parent Direct as advertised on the teddy bear's vest) as that service became rebranded. The Respect Agenda is still alive; and the apparently indestructible Sure Start as symbolized in the bendy, 
rubber figure remains practically a chimera. The remaining artifacts symbolize my ambivalence about circus project. The paper watch is ephemeral; the highlighter pen's meaning is neither transparent nor completely opaque. Rather than a hierarchically governed, evidence based policy with a set of stable brands and logos, what my analysis of the artifacts reveals is the ways in which policy is translated as it is implemented. Logos seek to impose specificity with virtual Children's Centres needing to meet centrally determined criteria before they can apply the policy logo yet Sure Start is a malleable brand. Made from year end left overs with public money, the locally produced circus commodities trouble the rationalist modernization agenda with a carnivalesque, discretionary "right performance". The strategically vague (Potter 1996) deployment of culture performed policy implementation - the partnership "delivered" but analysis of the artifact's exchange reveals the risky give-away. Rather than purely rational implementation of evidence based policy, what we see here is policy saturated with symbols and brands delivered through a set of performative practices. Local discretion and discursive negotiating practices are key to understanding how vague, contradictory and ambiguous policy statements articulated by Central Government translated into material outputs that shaped a set of unintended policy consequences at the local level.

[1] Freebie - noun Informal. something given without charge or cost, as a ticket to a performance or sporting event or a free sample at a store

References 
Bang, H. 2004. Culture governance: governing self-reflexive modernity. Public Administration, 82 (1), 157-190.

Baudrillard, J. 1983. Simulations. New York: Semiotext.

Butler, J. 1990. Gender Trouble. New York: Routledge.

Boje, D. 2001. Carnivalesque Resistance to global spectacle: A critical postmodern theory of public administration. Administrative Theory \& Praxis 23 (3), 431-458.

Carter, P. 2009. How welfare reform does and does not happen: a qualitative study of local implementation of childcare policy. Unpublished $\mathrm{PhD}$ thesis Keele University.

Clarke, J. 2005. New Labour's citizens: activated, empowered, responsibilized, abandoned? Critical Social Policy 25 (4), 447-463.

Clarke, J., Newman J., Smith N. and Vidler, E. 2007. Creating Citizen-Consumers Changing Publics and Changing Public Services. London : Sage.

CASAS What is the Respect Agenda?

http://www.csas.org.uk/upload/documents/webpage/Factsheets/Respect\%20Agenda.pdf [accessed 28 January 2011].

DfES 2003. Every Child Matters Cm 5860 London: The Stationery Office.

DfES and DH 2006 Industry Techniques and Inspiration for commissioners Crown Copyright http://www.dhcarenetworks.org.uk/_library/Industry_techniques_and_inspiration_for_commissioners.p df [accessed 29 January 2011$\}$.

DeVaus, D. 2004. Surveys in social research. London: Routledge.

Deleuze G. 1988. A thousand plateaus capitalism and schizophrenia. London : Athlone Press.

Derhardt, R. and Derhardt, J. 2000. The new public service: serving rather than steering. Public Administration Review 60 (6), 549-559. 
DiMaggio, P. and Powell, W. 1983. The iron cage revisited: institutional isomorphiosm and collective rationality in organizational fields. American Sociological Review 48(2), 147-160.

Donzelot, J. 1979. The Policing of Families. London: John Hopkins Press Ltd.

Fairclough, N. 2000. Discourse, social theory, and social research: The discourse of welfare reform Journal of Sociolinguistics 4(2), 163-194.

Finch, J. 1991. Feminist research and social policy. In Women's Issues in Social Policy, G. D. Maclean ed., London: Routledge.

Foucault, M. 1980. Power/Knowledge Selected interviews and other writings 1972-1977 by Michel Foucault edited by Colin Gordon Harlow The Harvester Press Ltd.

Fox, C.J. and Miller, H.T. 1993. Postmodern public administration: a short treatise on self-referential ephiphenomena. Administrative Theory \& Praxis 15 ( 1), 1-17.

Fraser, N. 1981. Foucault on modern power: empirical insights and normative confusions" Praxis International 3, 272-287.

Fraser, N. 1989. Unruly practices power, discourse and gender in contemporary social theory Minneapolis: University of Minnesota Press.

Gale, T. 1999. Policy trajectories: treading the discursive path of policy analysis. Discourse: Studies in the cultural politics of education, 20 (3), 393-407.

Gale, T. 2001. Critical policy sociology: historiography, archaeology and genealogy as methods of policy analysis. Journal of Education policy, 16 (5)379- 393.

Gewirtz, S., Dickson, M. and Power, S. 2004. Unravelling a 'spun' policy: a case study of the constitutive role of 'spin' in the education policy process. Journal of Education Policy Vol 19,(3) 321342.

Glass, N. 2005 “Surely some mistake?” Guardian 5 January 2005 [accessed 1 September 2010]. 
Glendinning, C. and Kemp, P. 2006. Cash and care policy challenges in the welfare state. Bristol: The Policy Press.

Hajer, M. 2009. Authoritative governance: policy-making in the age of mediatization. Oxford: Oxford University Press.

House of Commons Committee of Public Accounts (2007) Sure Start Children's Centres Thirty-eighth Report of Session 2006-7 Report, together with formal minutes, oral and written evidence.

Jessop, B. and Oosterlynck,S. 2008. Cultural political economy: on making the cultural turn without falling into soft economic sociology http://eprints.lancs.ac.uk/505/1/-_E-2007b_CPE-Geoforum.pdf [accessed 28 January 2011].

Jordan, B. and Jordan, C. 2000. Social work and the third way tough love as social policy London : Sage Publications Ltd.

Law, J. 1986. Power, action and belief a new sociology of knowledge? London: Routledge. Lash, S. and Urry, J. 1994. Economies of Signs and Space London: Sage Publications Ltd. Lister, R. 2002. A politics of recognition and respect: involving people with experience of poverty in decision-making that affects their lives' Social Policy \& Society, 1(1), 37-46.

Lury, C. 2004. Brands: the logos of the global economy. Abingdon: Routledge.

Malone, R. 1999. Policy as product morality and metaphor in health policy discourse" Hastings Center Report, 29(3), 16-22.

Maltby, T., Kennett P. and Rummery K. 2008. Analysis and debate in social policy Social Policy Review, 20 Bristol: The Policy Press.

Michel, S. and Mahon R. 2002. Child care policy at the crossroads gender and welfare state restructuring. London: Routledge.

Miller, C. and Stirling, S. 2004. Co-production in children's services. London: Office for Public Management. 
Mitchell, D. 2011. I'm glad the ASBO is going, but most rebranding is just a load of bull The Observer 13/2/11

Mosse, D. 2004. Is Good Policy Unimplementable? Reflections on the ethnography of aid policy and practice" Development and Change 35(4) 639-671.

NESS 2005. Early Impacts of Sure Start Local Programmes on Children and Families Research Report NESS/2005/FR/013 HMSO.

Newman, J. 2005. Remaking governance, peoples, politics and the public sphere. The Polity Press, Bristol.

Newman, N. and Clarke, J. 2009. Publics, politics \& power remaking the public in public services London: Sage Publications Ltd.

Pascall, G. 2008.Gender and New Labour: after the male breadwinner model? In Maltby et al.. eds. “Analysis and Debate in social policy” Social Policy Review 20 Bristol: The Policy Press.

Penn, H. 2007. Childcare market management how the United Kingdom Government has reshaped its role in developing early childhood education and care" Contemporary Issues in Early Childhood 8 (3) 192-207.

Potter, J. 1996 Discourse, Rhetoric and Social Construction London: Sage.

Pricewaterhousecoopers (2006) DfES Children's Services The Market for Parental \& Family Support Services http://www.education.gov.uk/research/data/uploadfiles/rw72.pdf

[Accessed 23 August 2010].

Rafaeli ,A. and Pratt M.G. 2006. Artifacts and organizations beyond mere symbolism. Mahwah, New .Jersey: Lawrence Erlbaum.

Ritzer, G. 2002. McDonalidization the reader. London: Sage Publications ltd.

Roberts, P. 2006. Nurturing creativity in young people A report to Government to inform future policy http://www.idea.gov.uk/idk/aio/5720952 [accessed 28 January 2011].

Rose, N. 1989. Powers of freedom reframing political thought. Cambridge: Cambridge University 
Press.

Rutter, M. 2006. Is Sure Start an effective intervention? Child and Adolescent Mental Health. 11 (3), $135-141$.

Sanderson, I. 2003. Is it 'what works' that matters? Evaluation and evidence-based policy-making Research Papers in Education. 18, (4), 331-345.

Seidman,S. and Wagner, D.G. 1992. Postmodernism \& social theory. Oxford: Basil Blackwell Ltd. Social Exclusion Unit 2006 A Sure Start to later life ending inequalities for older people London : Office of the Deputy Prime Minister.

Shore, C. and Wright, S. 1997. Anthropology of policy critical perspectives on governance and power London: Routledge.

Stone, D. 2002. Policy paradox the art of political decision making. New York: Norton and Co.

Taylor, M. 2003. Public policy in the community Basingstoke: Palgrave.

Tschirhart, M., Christensen R.K. and Perry J.L.2005. The paradox of branding and collaboration.

Public Performance and Management Review. 29 (1), 67-84.

Weick, K. E. 1995. Sensemaking in organizations. Thousand Oaks: Sage Publications Ltd.

Williams, F. 2001. In and beyond New Labour: towards a new political ethics of care. Critical Social Policy, 21; 467.

Willis, P. 2000. The Ethnographic Imagination. Cambridge: Polity Press

Wincott, D. 2006 “Paradoxes of New Labour Social Policy: Toward Universal Child Care in Europe’s “most liberal” Welfare Regime?” Social Politics: International Studies in Gender, State \& Society. 13 (2), 286-312.

Yanow, D. 1996. How does a policy mean? Washington: Georgetown University Press 
Table 1. Your title here.

Figure 1. Your title here.

Figure 1 Sure Start bendy figure

Figure. 2 Respect pen

Figure 3 teddy as toy

Fig.4 teddy as policy give-away

Figure 5 child's paper watch

Figure 6 highlighter pen 